\title{
TINJAUAN YURIDIS ASURANSI JIWA TERHADAP KESELAMATAN PENGUNJUNG OBYEK WISATA TAMAN WISATA ALAM GROJOGAN SEWU
}

\author{
Mustika Larasati \\ E-mail: mustika.larasati@student.uns.ac.id \\ Mahasiswa Fakultas Hukum Universitas Sebelas Maret Surakarta \\ Arief Suryono \\ Dosen Fakultas Hukum Universitas Sebelas Maret Surakarta \\ E-mail: ariefsuryono@staff.uns.ac.id
}

\begin{abstract}
This article aims to discover the construction of legal relations that occur between life insurance parties at grojogan sewu nature tourism park and their legal responsibilities. Legal relations are connections regulated by law that provides rights and obligations. Whereas legal responsibility here means that there are obligations and rights that must be fulfilled in accordance with both agreement and the applicable laws and regulations. The method used is of descriptive normative legal research. Based on the results of the research, construction of legal relations that occur between managers and insurance companies related to visitors as the insured that is each visitor insured by the manager to the insurance company. Managers with visitors, namely the relationship of buying and selling tourism services. An insurance company with visitors, in the form of a company obligation with visitors to a tourist park that is optional and must be insurance. The responsibility of the guarantor is facultative that means the insured are based there or not an evenemen, if no one evenemen the obligation for insurance companies was not there and otherwise, and tourist attractions that visitors obligation to pay premiums. Whereas in legal responsibility, the insured can ask for legal responsibility in accordance with the insurance agreement, namely fulfilment of material losses and if not satisfied, the insured can ask for legal responsibility in accordance with the law, namely in fulfilling immaterial losses. However, if the insured in this case still does not meet the meeting point, a settlement could be made. Disputes settlement could be carried out through litigation and non-litigation.
\end{abstract}

Keywords: insured; insurance; legal relations; legal responsibilities.

\begin{abstract}
Abstrak
Artikel ini bertujuan untuk mengetahui konstruksi hubungan hukum yang terjadi antar pihak dalam asuransi jiwa pada Taman Wisata Alam Grojogan Sewu dan tanggung jawab hukum bagi pengelola. Hubungan hukum adalah hubungan yang diatur oleh hukum yang menimbulkan hak dan kewajiban. Sedangkan tanggung jawab hukum disini dimaksudkan adanya kewajiban dan hak yang harus dipenuhi sesuai dengan perjanjian maupun peraturan perundang-undangan yang berlaku. Metode yang digunakan adalah penelitian hukum normatif bersifat deskriptif. Berdasarkan hasil penelitian konstruksi hubungan hukum yang terjadi antara pengelola dengan perusahaan asuransi berkaitan dengan pengunjung sebagai tertanggung yaitu setiap pengunjung diasuransikan oleh pengelola kepada perusahaan asuransi. Pengelola dengan pengunjung yaitu adanya hubungan jual beli jasa pariwisata. Perusahaan asuransi dengan pengunjung yaitu berupa kewajiban perusahaan dengan pengunjung taman wisata yang bersifat fakultatif wajib asuransi. Adanya tanggung jawab penanggung bersifat fakultatif berarti pada pertanggungan didasarkan
\end{abstract}


ada atau tidaknya suatu evenemen, apabila tidak ada suatu evenemen maka kewajiban bagi perusahaan asuransi itu tidak ada begitu pula sebaliknya, dan kewajiban pengunjung tempat wisata yaitu membayar premi. Sedangkan pada tanggung jawab hukum, tertanggung dapat meminta tanggung jawab hukum sesuai dengan perjanjian asuransi yaitu pemenuhan kerugian materiil dan apabila tidak puas maka tertanggung dapat meminta tanggung jawab hukum sesuai dengan undang-undang yaitu dalam pemenuhan kerugian imateriil. Namun apabila tertanggung dalam hal ini tetap tidak menemui titik temu maka dapat dilakukan penyelesaian. Untuk Penyelesaian sengketa dapat dilakukan melalui litigasi dan non litigasi.

Kata kunci : Tertanggung; Asuransi; Hubungan Hukum; Tanggung jawab Hukum.

\section{A. Pendahuluan}

Negara Indonesia adalah negara hukum, itulah bunyi Pasal 1 ayat (3) Undang-Undang Dasar 1945 setelah amandemen. Salah satu contoh kongkret negara hukum adalah adanya suatu peraturan perundangan-undangan yang bersifat mengikat dan memaksa. Sumber pokok hukum perdata di Indonesia ialah Kitab Undang-Undang Hukum Perdata (KUHPerdata). Apabila diperhatikan, bahwa salah satu yang diatur di dalam KUHPerdata sendiri adalah mengenai perikatan yang di atur pada buku ke tiga. Perikatan diatur didalamnya hak-hak dan kewajiban timbal balik antara orang-orang atau pihak-pihak tertentu. Adapun mengenai penjelasan tentang perikatan diatur dalam Pasal 1233 KUHPerdata, yang ditegaskan bahwa "Tiap-tiap perikatan dilahirkan baik karena perjanjian, baik karena undang-undang". Sehingga berdasarkan ketentuan tersebut dapat disimpulkan bahwa sebuah perikatan dapat lahir karena adanya suatu persetujuan atau perjanjian dan karena adanya undang-undang yang menentukan.

Perikatan erat kaitannya dengan perjanjian karena perikatan lahir salah satu sumbernya adalah perjanjian. Perjanjian diatur dalam Pasal 1313 KUHPerdata yang ditegaskan bahwa "suatu perjanjian adalah suatu perbuatan dengan mana satu orang atau lebih mengikatkan dirinya terhadap satu orang lain atau lebih". Perjanjian antara penanggung dan tertanggung sebagai suatu perjanjian asuransi atas kejadian yang dicantumkan dalam perjanjian yang timbulnya tidak dapat dipastikan. Sebagai suatu perjanjian, asuransi diatur dalam kitab Undang-undang Hukum Perdata dan Kitab Undang-undang Hukum Dagang. Asuransi sendiri secara spesifik diatur dalam Undang-Undang Nomor 40 Tahun 2014 Tentang Perasuransian. Manusia selalu dihadapkan pada suatu hal yang dinamakan risiko, Timbulnya suatu risiko tersebut menjadi kenyataan bahwa adanya sesuatu yang belum pasti. Sehingga kebutuhan terhadap perlindungan atau jaminan asuransi bermula dari keinginan untuk mengatasi ketidakpastian (uncertainty). Sehingga asuransi atau pertanggungan di dalamnya selalu mengandung risiko. Risiko termaksud terjadinya adalah belum pasti karena masih tergantung pada suatu peristiwa yang belum pasti pula (Sri Rejeki Hartono, 2001:12).

Setiap orang selalu ingin merasakan kenyamanan di manapun ia berada. Tidak terkecuali pada saat orang tersebut sedang menikmati harinya di daerah pariwisata. Merupakan hak bagi para wisatawan untuk mendapatkan jaminan keamanan, kenyamanan, keselamatan dari pihak pengelola dari tempat wisata manapun. Meskipun hampir setiap pariwisata sudah ikut serta kepada jasa asuransi tapi tidaklah menjamin seseorang untuk selamat dari suatu kecelakaan atau suatu risiko yang tidak diinginkan. Pariwisata sendiri diatur dalam Undang-Undang Nomor 10 Tahun 2009 Tentang Kepariwisataan (UU No. 10/2009). 
Obyek Wisata Air terjun Grojogan sewu sekarang ini dikelola oleh PT. Duta Indonesia Jaya yang sebelumya dikelola oleh Dinas Kementrian dan Kehutanan Tawangmanggu, Pengelola Obyek Wisata Air Terjun Grojogan sewu ini sudah melakukan perjanjian asuransi dengan perusahaan asuransi dengan bukti adanya polis asuransi yang diberikan kepada pengelola dari pihak perusahaan asuransi apabila ada risiko yang terjadi kepada pengunjung atau wisatawan. Asuransi tersebut diambil dari sebagian biaya tiket masuk yang dibayarkan oleh pengunjung sebagai premi asuransi.

Dalam pelaksanaan asuransi, wisatawan telah mengetahui berapa besar pertanggungan dari pihak penanggung melalui papan asurasi yang di pasang pada loket masuk obyek wisata. Keikutsertaan wisatawan sebagai pihak tertanggung merupakan suatu keharusan dan terjadi secara otomatis. Dengan memasuki obyek wisata dan membeli tiket masuk obyek wisata, berarti wisatawan telah mengikuti asuransi sebagai pihak tertanggung. Dengan adanya para pihak dalam suatu perjanjian, maka timbul hak dan kewajiban yang harus dipenuhi. Maka dari itu dirasa perlu untuk membahas mengenai bagaimana konstruksi hubungan hukum para pihak dan tanggung jawab pihak pengelola apabila terjadi evenemen.

\section{B. Metode Penelitian}

Metode penelitian yang digunakan oleh penulis dalam penulisan hukum (skripsi) ini adalah penelitian hukum normatif. Penelitian hukum normatif adalah penelitian hukum yang meletakkan hukum sebagai sebuah bangunan sistem norma. Sistem norma yang dimaksud adalah mengenai asas-asas, norma, kaidah dari per]aturan perundang-undangan, putusan pengadilan, perjanjian serta doktrin (ajaran) (Mukti Fajar dan Yulianto Achmad, 2010:34). Sifat penelitian yang penulis gunakan dalam penelitian hukum ini adalah penelitian deskriptif. Sifat Penelitian dalam penelitian ini bersifat deskriptif yakni menyatakan bahwa metode deskriptif adalah suatu metode yang digunakan untuk menggambarkan atau menganalisis suatu hasil penelitian.

Penulis menggunakan pendekatan perundang-undangan (statute approach) dengan dasar bahwa mengkaji isu hukum untuk mencari pemecahan terhadap isu hukum yang diangkat dalam penelitian hukum ini, dilakukan penelaahan terhadap regulasi yang berkaitan dengan isu hukum. Sementara sumber data yang digunakan berupa bahan hukum primer dan bahan hukum sekunder. Teknik yang dipakai dalam pengumpulan bahan hukum ini adalah studi kepustakaan dan studi lapangan. Teknik analisis bahan hukum yang digunakan dalam penelitian ini adalah analisis data secara kualitatif yaitu memadukan antara penelitian kepustakaan dan penelitian lapangan serta mengolah bahan hukum primer yang telah diperoleh dan akan dijadikan sesuatu yang utuh atau metode analisis.

\section{Hasil Penelitian dan Pembahasan}

Perjanjian asuransi yang ada pada Taman Wisata Alam Grojogan Sewu ini merupakan perjanjian asuransi oleh beberapa pihak yang merupakan subyek hukum yaitu perusahaan asuransi PT Asuransi Jiwa Syariah Amanah Jiwa Giri Artha sebagai pihak yang menyediakan fasilitas asuransi jiwa dengan pengelola utama taman wisata alam tersebut yaitu Kementrian Lingkungan Hidup dan Kehutanan Republik Indonesia cq Balai KSDA Jawa Tengah kemudian diserahkan kepada PT Duta Indonesia Djaya berdasarkan Surat Keputusan Direktorat Jenderal Perlindungan Hutan dan Konservasi Alam sebagai pihak perusahaan 
pengelola Taman Wisata Alam Grojogan Sewu. Perjanjian asuransi tersebut diperuntukkan bagi pengunjung dan petugas Taman Wisata Alam Grojogan Sewu. Pengunjung yaitu pihak yang menggunakan jasa pariwisata dan terikat dalam perjanjian asuransi yang ada atau pihak yang menjadi tertanggung bagi perusahaan asuransi.

Adanya hubungan hukum akibat adanya suatu perjanjian asuransi menimbulkan suatu hak dan kewajiban atau adanya suatu hubungan yang saling mempengaruhi yang harus dilaksanakan sesuai dengan isi perjanjian. Para pihak dalam perjanjian asuransi yang ada dalam Taman Wisata Alam Grojogan Sewu saling memiliki hubungan hukum yaitu antara pihak pengelola yaitu PT Duta Indonesia Djaya dengan pihak perusahaan asuransi yaitu PT Asuransi Jiwa Amanah Jiwa Giri Artha dan hubungan hukum antara pihak pengelola dengan pihak pengunjung taman wisata dan hubungan hukum antara pihak perusahaan asuransi dengan pihak pengunjung taman wisata tersebut.

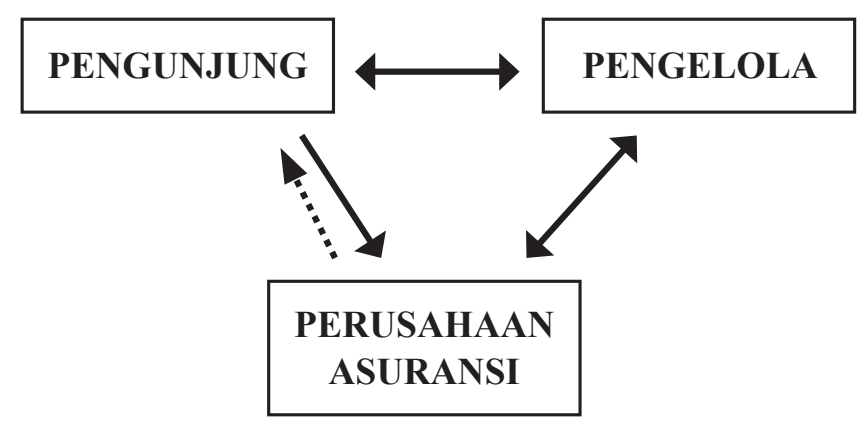

Hubungan hukum pengelola dan perusahaan asuransi berkaitan dengan pengunjung sebagai tertanggung yaitu setiap pengunjung diasuransikan oleh pengelola kepada perusahaan asuransi PT Asuransi Jiwa Amanah Jiwa Giri Artha. Pengelola dalam hal ini berkewajiban melaporkan akan terjadinya suatu risiko oleh tertanggung atau dalam hal ini dimaksudkan pengunjung wisata dan petugas wisata kepada perusahaan asuransi atas jasa yang telah diberikan. Sedangkan perusahaan asuransi berkewajiban menindaklanjuti adanya risiko yang dihadapi tertanggung dari pengelola dan melaksanakan pemberian manfaat kepada tertanggung sesuai dengan syarat-syarat dan ketentuan yang telah disepakati sebelumnya antara pengelola dan perusahaan asuransi. Pihak perusahaan asuransi berhak dalam penerimaan premi yang dibayarkan melalui pembelian tiket masuk oleh pengunjung kepada pengelola dan pihak pengelola juga berhak atas keuntungan dari adanya hubungan kerjasama yang diadakan dengan perusahaan asuransi terkait.

Adanya hubungan jual beli antara pengelola dan pengunjung wisata taman wisata alam grojogan sewu yaitu pengelola telah menawarkan jasa pariwisata obyek wisata yaitu taman wisata alam grojogan sewu kepada pengunjung. Kemudian pada saat pengunjung tertarik maka pengunjung membeli karcis tanda masuk tempat wiata tersebut. Saat pengunjung telah membeli tiket masuk wisata tersebut maka pengelola mengasuransikan pengunjung kepada perusahaan asuransi.

Pengunjung memiliki hak dalam keikutsertaannya sebagai tertanggung dalam asuransi jiwa yaitu hak untuk melaporkan kepada pengelola karna telah terjadinya suatu risiko dan pengelola dalam hal ini berkewajiban menerima laporan akan adanya suatu risiko tersebut kemudian menyampaikannya kepada perusahaan asuransi terkait. Pengunjung selain memiliki hak pokok dalam keikutsertaannya sebagai tertanggung dalam asuransi jiwa, dalam penerimaan manfaat ia juga memiliki kewajiban yaitu membeli tiket masuk pariwisata sebagai 
tanda bukti pembayaran premi kepada asuransi jiwa yang disediakan oleh pihak pengelola. Pihak pengelola dalam hal ini juga memiliki hak untuk mendapatkan sebagian keuntungan dari hasil pendapatan dari pembelian tiket masuk oleh pengunjung.

Secara yuridis produk hukum yang dapat dicermati terkait dengan pengaturan hukum terhadap wisatawan atau pengunjung wisata dan pengusaha pariwisata atau dalam hal ini pengelola wisata adalah Undang-Undang No. 10 tahun 2009 tentang Kepariwisataan. Hak wisatawan diatur dalam ketentuan Pasal 20 Undang-Undang No. 10 Tahun 2009 dan Kewajiban wisatawan sendiri diatur dalam Pasal 25 Undang-Undang No. 10 Tahun 2009. Hak pengusaha pariwisata diatur dalam ketentuan Pasal 22 Undang-Undang No. 10 Tahun 2009 dan Kewajiban pengusaha pariwisata sendiri diatur dalam Pasal 26 Undang-Undang No. 10 Tahun 2009. Di era globalisasi perlindungan hukum terhadap pengguna jasa pariwisata baik domestik maupun manca negara dan para pengusaha pariwisata sangat dibutuhkan. Pariwisata merupakan salah satu andalan dalam perolehan devisa bagi pembangunan baik nasional maupun daerah. Oleh karena sebab itu, pembangunan pariwisata Indonesia harus mampu menciptakan inovasi baru untuk mempertahankan dan meningkatkan daya saing secara berkelanjutan (Made Metu Dhana, 2012:1).

Kewajiban Perusahaan PT Asuransi Jiwa Syariah Amanah Jiwa Giri Artha dengan pengunjung Taman Wisata Alam Grojogan Sewu ini bersifat fakultatif karena bisa iya bisa juga tidak. Fakultatif berarti pada pertanggungan didasarkan ada atau tidaknya suatu evenemen, apabila tidak ada suatu evenemen maka kewajiban bagi perusahaan asuransi itu tidak ada. Begitu pula sebaliknya, apabila ada evenemen maka kewajiban bagi perusahaan asuransi itu baru akan muncul yaitu pemberian manfaat kepada pihak tertanggung atas telah terjadinya suatu evenemen. Kewajiban pengunjung tempat wisata yaitu membayar premi dengan membeli tiket masuk yang ditawarkan oleh pihak pengelola. Kewajiban perusahaan asuransi baru akan ada ketika telah terjadinya evenemen, sehingga dikatakan perjanjian asuransi dikatakan sebagai perjanjian bersyarat yaitu perjanjian yang melahirkan kewajiban apabila syarat-syarat yang dikenhendaki terjadi atau terpenuhi selama berlangsungnya asuransi.

Sesuai ketentuan yang ada dalam Pasal 20 dan 26 Undang-Undang No. 10 Tahun 2009 tentang Kepariwisataan, pada hasil penelitian menunjukkan bahwa pemenuhan hak wisatawan terkait keselamatan pengunjung tidak terpenuhi berkaitan hal hal yang di dapat yaitu terkait hanya adanya satu pos jaga di dalam lokasi wisata. Adanya satu pos jaga dalam lokasi wisata tersebut dirasa kurang dalam pengawasan dikarena tempat wisata yang luas dan kurangnya jangkauan pemantauan dari petugas wisata atau dalam hal ini BNPB (Badan Nasional Penanggulangan Bencoulda) untuk keselamatan pengunjung. Meskipun hanya ada satu pos jaga setidaknya dalam setiap titik lokasi wisata diberikan petugas untuk memantau setiap keadaan guna terjaminnya keselamatan pengunjung. Apabila terjadi suatu risiko, pada pengunjung sebagai tertanggung dapat meminta pertanggung jawaban hukum secara imateriil yaitu berdasarkan undang-undang dan pertanggung jawaban secara materiil yaitu berdasarkan perjanjian asuransi yang telah disepakati sebelumnya antara pihak pengelola Kementrian Lingkungan Hidup dan kehutanan Republik Indonesia yang diserahkan pengelolaannya kepada perusahaan PT Duta Indonesia Djaya dengan pihak perusahaan asuransi yaitu PT Amanah Jiwa Giri Artha. Pada kerugian imateriil, ganti rugi berapapun yang telah diberikan belum dapat dikatakan telah menutup kerugian apabila unsur kerugian itu masih ada. Apabila 
unsur kerugian tersebut masih ada maka ahli waris dari pihak tertanggung dapat melakukan gugatan kepada pihak pengelola.

Apabila pengunjung selaku tertanggung dalam perjanjian asuransi merasa tidak puas atau sedang dalam perselisihan dengan pihak penanggung yaitu perusahaan asuransi maupun pihak pengelola makan dapat dilakukan penyelesaian. Untuk Penyelesaian sengketa dapat dilakukan melalui litigasi dan non litigasi. Penyelesaian sengketa non litigasi atau penyelesaian sengketa di luar pengadilan dapat diarahkan melalui BMAI atau Lembaga Alternatif Penyelesaian Sengeketa (LAPS) yang ditetapkan oleh Otoritas Jasa Keuangan. Apabila tidak puas dengan penyelesaian eksternal non litigasi, tertanggung tentu dapat mengajukan dalam proses pengadilan menggunakan hukum acara yang berlaku. Namun proses peradilan pada dasarnya berlangsung lebih lama dan memerlukan biaya tidak sedikit dibandingkan dengan penyelesaian non litigasi.

\section{Simpulan}

Para pihak dalam perjanjian asuransi yang ada dalam Taman Wisata Alam Grojogan Sewu saling memiliki hubungan hukum yaitu konstruksi hubungan hukum yang terjadi antara pengelola dengan perusahaan asuransi berkaitan dengan pengunjung sebagai tertanggung yaitu setiap pengunjung diasuransikan oleh pengelola kepada perusahaan asuransi. Pengelola dengan pengunjung yaitu adanya hubungan jual beli jasa pariwisata. Perusahaan asuransi dengan pengunjung yaitu berupa kewajiban perusahaan dengan pengunjung taman wisata yang bersifat fakultatif wajib asuransi. Pada tanggung jawab hukum pengunjung sebagai tertanggung dapat meminta pertanggungjawaban hukum secara imateriil yaitu berdasarkan peraturan perundang-undangan dan pertanggungjawaban secara materiil yaitu berdasarkan perjanjian asuransi yang telah disepakati sebelumnya antara pihak pengelola Kementrian Lingkungan Hidup dan kehutanan Republik Indonesia yang diserahkan pengelolaannya kepada perusahaan PT Duta Indonesia Djaya dengan pihak perusahaan asuransi yaitu PT Amanah Jiwa Giri Artha. Adanya asuransi belum tentu membebaskan dari tanggung jawab hukumnya. Sepanjang unsur kerugian sudah tertutup, pengelola bebas dari tanggung jawab hukum begitu pula sebaliknya. Apabila pengunjung selaku tertanggung dalam perjanjian asuransi merasa tidak puas atau sedang dalam perselisihan dengan pihak penanggung yaitu perusahaan asuransi maupun pihak pengelola maka dapat dilakukan penyelesaian.

\section{E. Saran}

Kepada pihak pengelola (PT Duta Indonesia Djaya) lebih mengutamakan keselamatan pengunjung wisata dengan memberikan petugas BNPB di berbagai titik lokasi yang rawan terjadi kecelakaan dan pihak pengelola lebih memberikan informasi secara rinci terkait asuransi jasa pariwisata yang ada dalam Taman Wisata Alam Grojogan Sewu. Bagi pemerintah daerah diharapkan dapat meningkatkan insfrastruktur Taman Wisata Alam Grojogan sewu sehingga lebih menarik minat wisatawan baik lokal maupun mancanegara. 


\section{F. Daftar Pustaka}

Achmad, Mukti Fajar dan Yulianto. 2010. Dualisme Penelitian Hukum Normatif dan Empiris. Yogyakarta: Pustaka Pelajar.

Hartono, Sri Rejeki. 2001. Hukum Asuransi dan Perusahaan Asuransi. Jakarta: Sinar Grafika.

Made Metu Dhana. 2012. Perlindungan Hukum dan Keamanan Terhadap Wisatawan. Surabaya: Paramta.

Prakoso, Aditama Setya dkk. 2016. Polis Asuransi Jiwa Sebagai Alat Bukti Penuntutan Klaim Dalam Perjanjian Asuransi Jiwa (studi) di PT Asuransi Jiwasraya Semarang Timur. Diponegoro Law Journal. Volume 5 Nomor 3. Semarang: FH UNDIP.

Purnomo, Agus. 2017. “Analisis Pembayaran Premi Dalam Asuransi Syariah”. al-Uqud: Journal of Islamic Economics. Volume 1 Nomor 1. Banjarmasin: Universitas Islam Kalimantan.

Sunarmi. 2015. “Pemegang Polis Asuransi Dan Kedudukan”. Jurnal Ilmu Hukum. Volume 3 Nomor 1. Riau: Universitas Riau.

Winastri, Rivo Krisna dkk. 2017. "Tinjauan Normatif Terhadap Ganti Rugi Dalam Perkara Perbuatan Melawan Hukum Yang Menimbulkan Kerugian Immateriil (Studi Kasus Putusan Pengadilan Negeri Istimewa Jakarta No. 568/1968.G)". Diponegoro Law Journal. Volume 6 Nomor 2. Semarang: FH UNDIP. 